Journal of Social Sciences 4 (3): 178-188, 2008

ISSN 1549-3652

(C) 2008 Science Publications

\title{
The Logic of Populist Discourse and its Cultural Frame in Korea: An Analysis of the Former President Roh Moo-Hyun's Reformist Rhetoric
}

\author{
Manwoo Lee \\ College of Social Sciences, Sungkonghoe University \\ Welfare and Labor Team, National Assembly Research Service \\ 1 Youido-Dong, Yongdeungpo-gu, Seoul, 150-701, Republic of Korea
}

\begin{abstract}
This study was conducted to explain the discursive logic of populist politics and its cultural background in the former president Roh's Korean Government. It was divided into two parts of research results. In the first part, I articulated a reading of former Korean president Roh's discourses focusing on the populist dimensions of his rhetoric. His discourse was organized according to the binary opposition of antagonism. It distinguished between us (the People as represented by his Government) and them (the Conservatives the majority party in the National Assembly), constructing thus two chains of equivalences at war. In the second part, I explored the socio-historical conditions of emergence of populist discourses by trying to situate the outbreak of current populism within the long history of past social movement in Korea. I confirmed manic dualism as a cultural frame of Korean populism in relation to the crucial cleavage between the conservatives and the progressives that have seemed to dominate contemporary Korean political culture. And coming to a conclusion, I discussed the connection between Korean populism and democracy as a clinical diagnosis of populist discourses. Populism could be conceived as paradoxical experience in which the successive democratization in Korea might have become its underside.
\end{abstract}

Key words: Populism, conservative/progressive, binary opposition, manic dualism, democracy

\section{INTRODUCTION}

In December 2002, after the victory of selfproclaimed reformists in past presidential election of South Korea, the former President Roh Moo-hyun established his so-called Participatory Government and appointed any new politics of social justice and national integration, different from the existed politicians for the Korean people.

For instance, the newly committed public promises in a confabulation with AMCHAM (The American Chamber of Commerce in Korea, on 17 January 2003), a series of reforms aimed at revising the Korean legal apparatus in relation to issues of market principles. He singled out correcting the distortion of carrying on market enterprises, introducing class-action suits related to a bond and, more obvious, expelling varieties of accounting fraud, false announcements and stock price manipulations. For small stockholders, as well as for a section of progressive intellectuals this proposal was a necessary measure in order to ensure respect for transparency of auditing and, in particular, to prevent discrimination against them. Needless to say, this was a view not shared by many entrepreneurs. The reason for them to oppose this proposal was that it would hinder the autonomy of market sectors to engage in business.

In any case, this class-action suits has triggered an extraordinary reaction on behalf of the Korean people, a reaction that has polarized Korean society and has dominated political life and media coverage for the most part of 2002 and 2003. The Government led a campaign to consent to the class-action suits, articulating a discourse that was marked by an undeveloped economic ethic. Beginning from the premise that the class-action suit is not a mere legal document or institution of playing the stock market but a proof of economic personality, the men who were willing to legislate it, off the record, characterized the introduction of class-action suits as a revolution on the economic level and started a struggle to perform it. This struggle included mass rallies in stock markets attended by hundreds of thousands of people, interventions of internet media-which started following President Roh day in and day out in order to report their latest attack on the enterprisers-and a campaign to obtain consent from the people.

The polarization was also reflected within political structures and the party system: Hanara Dang, the largest conservative-right party, supported almost 
unconditionally the enterprisers that conservative journalists had begun to call holy warriors to revive our economy (The Monthly Chosen, 30 Sep. 2003). In opposition to this, Yeolin Uri Dang, the smallest reformist-left party that was supporting President Roh, held the same view as the government in relation to the class-action suits.

At the same time, it revealed that the Government was unable to mobilize the majority of its supposed following on such an apparently crucial issue. At any rate a deep split has been established in Korean public space and no obvious solution has been visible since both the government and its opponents were holding firm to their positions.

Setting the tone of what was to be addressed before, President Roh responded that on this issue 'only one factor existed and that was the people, that could not and should not have been ignored.' (An Interview with Financial Times, on 17 September 2003).

This was generally viewed as a clear prioritizing of the secular model of neutral rule of Law over the identification of political utopia over and above the Law that the government was putting forward. It was even more damaging because it was coming from someone whose institutional position, huge popularityhigher than President Roh's-and progressive intellectuals left no obvious strategy for the government to continue its struggle at the same level of intensity without creating a national schism.

At that time, the president has offered some sort ofat least temporary-solution. It seemed that his intervention or attitude have punctuated the whole struggle and retroactively marked a turning point. As a whole cycle of political mobilization and discursive articulations on behalf of the government have come to a close temporarily, it is perhaps time to sketch a set of analytic hypotheses on populist politics. Needless to say, analytic arguments are not articulated in a vacuum, but will be built on cultural foundations in Korea and develop further some of the points already led by psychoanalytic social theory.

Although deeply suspicious of any ideal of neutrality, I will try in what follows to avoid the polemical style that has characterized most academic and non-academic discussions associated with populist discourses and their politics.

\section{MATERIALS AND METHODS}

Data production: It is a common mistake to think that narrative data for discourse analysis are somehow simply out there and thus discovered and collected like picking strawberries from the vine. On the contrary, what constitutes narrative data depends on studying subjects' inquiry purposes and the questions they seek to answer. Narrative data are generated or produced within conceptual schemes and by various means that are deemed appropriate to serving particular purposes and answering particular questions.

In order to demonstrate my approach to analyzing unstructured qualitative data, I took some extended and detailed narrative examples including President Roh's speeches, addresses and remarks from websites. The main sites are as follows:

- CHEONG WA DAE Office of the President, Korea (http://www.president.go.kr/warp/app/home/kr_ho me)

- KukJung (State Affairs) Briefing (http://www. news.go.kr/warp/webapp/home/kr_home)
- Korea.net Gateway to Korea (http://www.korea.net/)

In contrast to the widespread tendency in quantitative research to fragment data by using code and retrieve methods, I illustrate not only the need for theoretically informed interpretation but also how I did it, based on what principles.

This study is structured around an account of the process of doing a piece of qualitative research on Korean populism, a topic that is eminently suitable for study from a psychoanalytic point of view because of the inherently subjective nature of the topic and the widely-recognized inadequacies of quantitative-mostly survey-based-studies to explain populist politics.

Discourse analysis: In this discussion research I understand discourse in a broad sense as encompassing all meaningful constructions (brief structures, construction of reality, cultural practices) through which social reality is produced and our action within it-especially our political action-acquires cause and direction. In that sense, a rigorous theoretical approach to the analysis of discourse has to take into account the fact that ideological construction emerges in a dialectic with something that exceeds its symbolic and imaginary boundaries.

The first detail pertains to the political. Politics happen precisely because a cultural frame is never complete. If a cultural frame were able to reach full closure, it would exclude the political. Because of the eternal undecidability of the discursive practices, however, politics acquire a central role within all practices at that moment when undecidable frames, demanding a conclusion or closure, become partially fixed. Discourse analysis is a political analysis of the 
way contingent relations become fixed in one way, but could have been fixed in many others.

I focus on the fact that discourses are created and changed in populist discursive practices and therefore stress the need for systematic empirical analyses of President Roh's spoken and written language in, for instance, the mass media or legwork interviews. My other focus is more concerned with general, overarching patterns and aims at a more abstract mapping of the discourses that circulate in society at a particular moment in time or within a specific cultural frame. Concerning the before-mentioned two levels of discourse analysis, the point is on differences of degree rather than qualitative differences. Although the former focuses on President Roh's everyday political action, it constantly implicates larger cultural frameworks on which he draws, or transforms, in discursive practices. And although the latter is mostly interested in more abstract, de-personified discourses, the ideology that these discourses have created, maintained and changed in myriads of everyday political action and discursive practices is implicit in the political theory.

However, at the same time, the different levels on the analytic continuum reflect differences in theoretical emphasis: the textual level of analysis is much more interested in President Roh's active and creative use of discourse as a resource for accomplishing political actions in specific contexts of interaction than the contextual level, which instead is interested in how discourses, more generally, limit a cultural frame for or against political action.

For me, the purpose of research is not to get behind President Roh's discourses, to find out what he really meant when he said this or that, or to discover the reality (the Real in Lacanian Terms) behind his discourses. The starting point is that reality can never be reached outside discourses and so it is discourse itself that has become the object of analysis. In discourse analysis, the primary exercise is not to sort out which of the statements about the politics in the research material are right and which are wrong (although a critical evaluation can be carried out at a later stage in the analysis). On the contrary, I worked with what has actually been said or written, exploring patterns in and across the statements and identifying the socio-cultural consequences of different discursive representations of reality.

In fact, it could be argued now that two criteria are essential concerning the discourse analysis of the emergence of Korean populism.

Two analytic criteria of populism: The Korean case is almost unique in its clear-cut picture, historical background and socio-political significance. The term populism is not used here in its polemical sense, as it is usually the case, but primarily as a tool of discourse analysis. Thus, before embarking upon my analysis, I am willing to clarify what exactly we mean by populism since this concept has been often attacked for its vagueness and its analytical effectiveness.

In defining populism, I take my lead from the theory of populism introduced by Ernesto Laclau in his texts Towards a Theory of Populism ${ }^{[8]}$ and Populist Rupture and Discourses ${ }^{[7]}$. What is Laclau arguing regarding the analysis of populism? First of all, one has to take into account the political subject addressed and invoked in a given discourse: Is it a nation? Is it a particular class or section of the population? Or is it people? According to Laclau, despite wide diversity in the uses of the term, we find in all of them the common reference to analogical basis which is the people...it is certainly true that reference to the people occupies a central place in populism ${ }^{[8]}$. However, the central place of signifier like the people does not seem enough to justify talking about populist discourses, although it does constitute the first important criterion. If the structural location of the people was enough to define populism, then the majority of political discourses required for the reform of a society would probably belong to the populist family. Laclau was from the beginning aware of this problem; hence the introduction of his second criterion for distinguishing populism: For popular positionality to exist, a discourse has to divide a society between the dominant and the dominated; that is, the system of equivalences should present itself as articulating the totality of a society around a fundamental antagonism ${ }^{[7]}$. As he has pointed out, the presence of popular elements in a discourse is not sufficient to transform it into a populist one. Populism starts at the point where popular-democratic elements are presented as an antagonistic option against the ideology of the dominant bloc ${ }^{[8]}$. Surely what gives the people its political salience and hegemonic appeal within populist discourses, is its antagonistic political representation.

Is the discourse articulated by President Roh and his government (and supporters in Korean civil society) a populist discourse? Does it fulfill the two criteria highlighted by Laclau: A central reference to the people and an antagonistic discursive logic? These will be the questions guiding my argumentation in the following.

\section{RESULTS AND DISCUSSION}

The status of the people (A Central Reference): Let us initially explore the first question, the status of the 
people in President Roh's discourse. Before the political crisis caused by the bribery case of his staffs and probing into the source of illegal funds for the presidential election in 2002, the people is not assigned any privileged status in his discourse; signifiers like nation-development and democracy mediating dialogue and negotiation are largely preferred. It is the political crisis that leads to a radicalization of Roh's discourse and to the necessity to address the people directly. This change of focus is also depicted in the officially published transcripts of his speeches, in the 4th Discussions for Administrating State Affairs of Participatory Government on 7 December 2003, where Kukmin-the Korean word for the people-is regarded as a force that can maintain the Government. It is obvious then that 'the people' is now becoming central, one of the master signifiers at play; it also becomes a constant reference which is to be found in abundance in almost every paragraph if not in every sentence.

Considering the status of the people from the reverse angle, the message is also crystal clear: the government assumes the role of the leader of the faithful people in its desperate attempt to defend its instrumental self-consciousness (Cheong Wa Dae's Briefing on the State Affairs in Participatory Government, on 30 December 2003). Roh's main concern is that the government has to fulfill its duty to the people of Government: The People is a President. It is representing and defending the people against the attack of conservatives and their party that ignores and opposes any national tasks guaranteed by reformist tradition. More significantly, the conservatives and their party are to be resisted on the grounds of its distance from the people. According to President Roh, contemporary Korean conservatives are characterized by living apart from the people, isolated from its popular ways of life. This is what, within this discursive universe, explains and condemns their anti-national characteristics. This is also what serves to legitimize and justify his position.

The Government is presented as eminently qualified to perform this task of political representation since there is no division between public servants and the people: Our public servants are a part of the people, kneaded with the People, working for the People, coming from the People (A Letter of the President sent to the National Public Servants, on 26 December 2003). The public servants consist of persons devoted to the Government and its people. Replying to criticism that the government has no right to speak on behalf of the people since it does not get the whole support of the people, he reasserts his right to speak in the name of the people and vows to continue to do so on the grounds that when he speaks about the Korean people he means the faithful of Participatory Government, the people of the government and not the conservatives skeptical to his government. There is no doubt that the notion of the people does have certain political connotations and a consolidated pattern within political discourses in Korea. Therefore, it seems that the people are used by him in a clearly political way. For example, it is he himself who stresses the quantitative parameter of this people: since, according to him-and the available statistical data-extreme conservatives opposed to the reform of Korean society comprise below $5 \%$ of the Korean population. This is supposed to legitimize his discourse on behalf of the Korean people in general, the people that every day judge and confirm its trust on us. Nowhere else in the democratic world are the people and government so close ... that's why the people expects support from the government, that's why the government speaks on behalf this people (A Dialogue with High-level Bureaucrats in Main Bureaus, on 20 June 2003). It becomes clear that the expression the people of Government is not used in the ethical sense, but as a statistical and territorial reference, a rhetorical device designed to mobilize supporters-through the establishment of a particular relation of representationand to terrify his opponents. The argument put forward is that virtually all Korean citizens, virtually the whole Korean population, support the government in its struggle against the conservatives. Such an instrumental, political conception of the people is often retrieved when the government feels threatened by its opponents or supported by popular mobilization of civil movement groups including Nosamo (those who love Roh Moo-hyun), Kuminyeuhim (People's Power), KukminChamyo 0415 (People's Participation 0415) is required to sustain it; this was also the case with the political crisis of the forthcoming General Election in 2004. As soon as crises were rising, the people could not help losing its value for the central position and is returned to silence, to the margins of political life.

The profoundly political references to the people by President Roh raise the issue of the relationship between the people and Government. By claiming to represent the people politically, Roh knows that he enters a dangerous field: the views of the people can change over time, while his position (presented as the landowner of reformist authority and, ultimately, the bearer of government discourses) is not allowed to change. The result is hybrid discourse. On the one hand, as a political discourse, government discourses are based on strong fundamentalism and representationalism rather uncharacteristic of populist ideology. They are beyond negotiation. They are 
authentic and revelatory and come from our people themselves ... The Participatory Government thus, when it speaks with words of the people, is not doing it the way a university professor does it for his science or a naïve politician for his ideology. The government does not speak a word of its own logic, it is transmitting words of the people (An Interview with Journalists in the Province of Guangju and Jeonnam, on 17 September 2003). Elsewhere, Roh states that, The government could be unmistakable, because the people is leading it (The 51th Committee with Chief Presidential Aides, on 14 August 2003). It is not hard to see how government discourse, in its profoundly political sense, can function within such a discourse that claims the people as first source of its legitimation. As we know, though, the government operates on the level of both ideology and policy. Any confusion is resolved first by attributing to the Korean people the quality of the Good, the people avec the government, i.e. the people of Government. On the other hand, a strong link is articulated between government discourses and words of the people. If both are presented as overlapped, then President Roh can claim to represent both without any contradictions. Hence, for him words of the people become government discourses: The People is a President. We cannot help naming this analogy a standard populist theme.

Thus, the president becomes the direct political representative of words of the people and the government ultimately acquires the role of the guarantor of this direct political representation, having entrusted this role to the president. In the presidents own words: I was given by the Government this responsibility, to move forward and for you to follow your Head (A Dialogue with Public Servants in the Ministry of Government Administration, on 11 August 2003). Here, the metaphor of a Head also reveals the organizational aspect of this discourse, a direct relationship between the leader and the led without mediating mechanisms, with the president and the government hierarchy in the roles of mere transmitters (something, by the way, not entirely consistent with orthodox government organization). In any case, the emphasis is clearly on the leaders charisma-cultivated by the tense media attention and the president's initially positive response to the challenge of mediation-and on the necessity for direct, unmediated rapport between the leader and his people ${ }^{[10]}$.

This stress on direct representation and on a populist style of organization explains the attacks of the president on any other mediating mechanisms that would occupy and regulate the space between him and his people. Hence the typical populist distrust of Law and Rights: Laws, when the people does not want them, are not applied, they fall into inactivity and are essentially abolished. They are rejected by the consciousness of the nation on what is right and what is not (An Emergent Press Interview in relation to the Reconfidence, on 11 October 2003). Although undoubtedly true (since, on the ontological level, constitutional and legal frameworks are social and political constructions), within the fundamental and political discourse of the president, this claim clearly functions as an attack on the constitutional basis of liberal democracy. By legitimizing his role as the direct and only true political representative of the people, it also invests the majority with a divine legitimatization: It is a powerful idea because it plays on the tension in democracy between the power of popular sovereignty and the possibility of a tyranny of the majority (An Interview with Journalists in the Province of Jeonbuk, on 25 November 2003).

The crude majoritarianism of government discourses, revealed in its mobilization behind the propaganda for the re-confidence, seems to be based on a neglect for the rights of minorities and an impatience towards what are presented as legalistic restrictions that may stand in the way of reform ${ }^{[2]}$. In other words, a populist modality of discourse is crucial for Roh's government because it makes possible to acquire democratic credentials without accepting the democratic politics of representation ${ }^{[12]}$.

The discursive Logic (A binary opposition of antagonism): In order to ground in a conclusive way the populist character of this discursive hybrid, it is necessary to examine the discursive logic dominating its organization and articulation.

Describing the attitude of the government before this political crisis, the president himself points out that it was not antagonistic towards his opponent forces since they would harm the people who are citizens of the state and faithful to the government. Consequently, after the crisis, we can assume that it must be same populist priority that obliges Roh and his government to adopt an antagonistic attitude. The binary opposition of antagonism is always between the people and its direct political representative, head of the government, on the one side and the opposite of the government and all the social forces supporting its decisions, on the other. The enemy is clearly secular power in the National Assembly that has kept distance from the people and stopped discussing with the government on issues concerning everyday life of the people (An Interview with Participants in Asia-Euro Press Forum, on 29 September 2003). This claim is also historically 
contextualized: History proves that the good government has always been attacked by the powerful of the moment but finally emerged victorious. And it was attacked because it did not succumb to the secular power. Because it did not fall into the conservatism and did not follow its orders, orders that are against the profit of the people (An Interview with Financial Times, on 17 September 2003). It becomes obvious here that it is particular attributes of the conservatives and their social supporters that become the primary targets of President Roh. Furthermore, these targets are presented in Roh's dramatized quasi-eschatological discourse as comprising the forces of evil, fighting against the government and trying to upset a general trend of our social development only because they hate the government of the people and wish to push it to the margins of social life. Now generally speaking, what can be these forces of evil, the antagonistic enemy of the government and its people?

The conservative politicians are clearly one of them: The conservative politicians lead the nation to downfall by dividing our society into several regional terrains and slash the ethical values of politics in national integration by fixing the politics of extreme regional emotions (A Reception with Figures dedicated their time to Democratic Movement in Foreign Countries, on 23 September 2003). Another is often the conservative intellectuals. Consider, for example, President Roh's polemic against distinguished Korean intellectuals that criticize him and his policies. Unfortunately some of our intellectuals want persistently to denounce the principle of selecting ministerial colleagues in sustaining our partnership. And he concludes: To these conservative intellectuals, who want at all cost to transform Korea into a country that will not recognize the line of policies or sense of political value and will not lean on it, we say clearly: You are wasting time... The people of government are not following you. You will be left again alone. You do not express the People... All the other Koreans are resisting your plans (The 54th Committee with Chief Presidential Aides, on 28 August 2003). This antiintellectualist attitude, coupled with the constant reference to the people reveals again the populist mode of Roh's discourse. It is also the case that this is a typical populist politics to the extent that populism in some of its different forms has not expressed hostility towards theoretical criticism and intellectualism ${ }^{[12]}$.

Even more revealing from the antagonistic content of this discourse is its style and, in particular, the war metaphors, which are numerous. An antagonistic climate of war and struggle is dominant here, with the medias becoming battle fields in the struggle between communicative politicians (reformists) and factional politicians (conservatives) (A Celebratory Speech in the Ceremony of Broadcasting Day, on 2 September 2003). It is not coincidence then that President Roh himself has offered the most graphic image of this struggle by holding the banner of any dialogue and negotiation, a symbolically charged emblem of the struggle against the conservatives. From a semiotic point of view, the aims of this move are obvious. A new antagonism is grafted onto a system of signification pertaining to a different context and a different period in order to acquire some of its mobilizing power and popular appeal. On top of this, he states that we are facing a new battle of political reform, with corrupt politiciansapparently a metaphorical expansion for the politicians belonging to regionally founded parties-threatening our healthy political culture (A Presidential Letter sent to the National Assembly in relation to the Legislation for Political Reform, on 17 December 2003).

After the political crisis, this antagonistic discursive organization was present in another form of all the forces conspiring for political corruptions. In fact, the president has spoken openly about the political corruption and its cleaning (A Speech of State Affairs in National Assembly, on 13 December 2003). The president has been constantly overstating the dangers of political corruption for the Koreans and the possibility of cultural obliteration and alienation due to the political partisanship based on a certain region and illegal funds. Clean Politics Deconstructing the unnecessary regulations, Reforming the System and Political Development were other usual references. In order to avoid all these dangers he seemed willing to consider even an alliance between social forces obtaining moral faith from the people. The change articulated by the governmental hybrid populism is that this time internal enemies are added to external threats made by the conservatives in the National Assembly and their supporters. The danger here for the government and its internal members-not external conspirators of the political corruption in the peoplewould be to contaminate the purity of the people of the government as represented by President Roh. This possibility, however, can be avoided by attributing their actions to the influence of ideologies akin to the reformist tradition: the agents of these ideologies are deemed worthy of being reformists and thus the essential progressive identity defended by the government retains its supposed purity and the symbols of past struggles for democratizing Korean society can be utilized in the new struggle without contradictions.

There is no doubt that Roh's discourse is organized according to the binary opposition of antagonism. It 
distinguishes between Us, the forces of Good (the People as represented by the Government) and Them, the forces of Evil (the Conservatives and their intellectuals, the majority party in the National Assembly), constructing thus two chains of equivalences at war with each other. In fact, the splitting introduced is so strong that the president falls short of assuming full responsibility for it. Presenting the mobilization of the government as an automatic and justified reaction, he blames his political opponents for splitting. When he is criticized for dividing the people, he replies that, in fact, he is interested in the unity of the people and social consensus: the splitting is not caused by us, but by those who created the political absurdities and irregularities. To them one should address the recommendations for the unity of the people. Those who oppose any progress to political reform are the ones to blame for the artificial splitting of the people and the nation (A Interview with Journalist in the Province of Daejun and Chungnam, on 12 October 2003).

Yes, a deep social rift is emerging, he acknowledges, but this can only be due to the action of the conservatives of every color, who could easily make Korea a state without political reform and the Korean a people without hope (A Presidential Letter sent to the National Assembly in relation to the Legislation for Political Reform, on 17 December 2003).

Now, I can assert that in terms of both his references to the people and antagonistic discursive logic, President Roh seems to be adopting a populist discursive style. If any populist politics are, more or less, unavoidable within the history of past social movement, there is no doubt that this particular politicization of populist discourses poses some important questions for social theory and political behavior founded on any cultural frame in Korean history.

The Emergence of populist discourses and its sociohistorical context: Therefore, I will try to situate the preceding analysis within the whole discussion of cleavage between the conservative and the progressive which, as it has been suggested, marks contemporary Korean political culture throughout.

The emergence of current populist discourses and new political identities is usually related to the dislocation, i. e. crisis of previously hegemonic discursive orders. It is a certain failure of previous identifications that forces subjects to seek refuge in a new discursive attachment and investment ${ }^{[7]}$. In Laclau's Words: The emergence of populism is historically linked to a crisis of the dominant ideological discourse which is in turn part of a more general social crisis ${ }^{[8]}$. This was for example, the case with Peronism in Argentina: The invocation of a sense of crisis was key to Peron's rise and also buttressed the importance of leadership ${ }^{[1]}$.

As far as the Korean case is concerned, this pattern seems to be once more reproduced. The increasing centrality of the reformist government since the late 1990s and the popular response to initiatives like the petition for a re-confidence to pass the political crisis have to be seen against the background of a variety of external and internal dislocations marking the late eighties and early nineties in Korea: these include internal political occurrences (scandals, corruptions, etc.) leading to increasing cynicism and political alienation, as well as international events entailing the collapse of the ideological division between Socialism and Capitalism. All these events helped the development of a reformist sentiment given that the governmental support of the dictatorship was being gradually forgotten. My hypothesis, however, is that what acted as a catalyst in all these ideological fermentations and displacements was the dislocations produced by societal democratization since the late 1980s in Korea. Indeed, it has been observed that both the upward turn in government in Korea and the shrinking of the number of those totally alienated from the government coincide with increasing the demand for reforming Korean society and the new challenges this involves. Political subjects previously tied to traditional discourses and demands that were marginalized by the new challenges, incapable of adjusting to the status and alienated from the new style of political discourse, may have comprised a reservoir of tentative followers from which populist politics could draw support. What happened then might have been an interesting reversal, revealing the inherent contradictions of reform and democracy. If, in the beginning of the democratization in Korea politics provided a functional alternative to it, or in Marxist terms, the conditions under which hope loses its fantastic guise and gains the clear-eyed unity of scientific theory and political practice, now we may be witnessing the opposite trend. The fact, however, that this fetters democratization or politics at the edges of democracy has taken a populist direction may lead to another hypothesis which connects this pattern of current populism to the populist legacy of Korean history.

For example, there is no doubt that the revolutionary populism (Minjungchui, Antiimperialistic and Anti-Fascistic people's ideologies) of the late 1970s and 1980s did exhibit similar 
characteristics with current populism. In those ideologies the people was not only addressed (very much like in President Roh's discourses) but also it was attempted to simplify the social topography along an antagonistic logic of discourses, stressing the split between them (the dominant sectors, the power-bloc) and us (the oppressed and the dominated sectors). The social base, identified as the under-privileged is mobilized against the enemy, namely the privileged, while the political space is divided simply into the Right and Left like the populist discourse in the age of democratization since 1980s in Korea, Minjung Damron (the people's discourse) have presented. If it is so, apart from this structural analogy, consider that there is a more direct historical link between the two.

Cultural criticism (manic dualism): My argumentation of Korean populism also needs to be situated within the broader discussion regarding the general profile of Korean political culture in order to confirm its cultural frame. In particular, the question of populism has been explicitly linked to an account of Korean political culture that understands political space as divided between two cultural camps: traditional conservatives and liberal progressives. This manic dualism thesis has been put forward in its paradigmatic form by Wells, Duncan and Kang ${ }^{[6,13,14]}$. In essence, this schema implies that due to the fact that the construction of a modern state in Korea entailed the introduction of a variety of western institutions and their accompanying logics and their grafting onto traditional and precapitalist, indigenous structures, what ensued was a situation of intense social, political and cultural struggles in which potential beneficiaries and potential losers in redefinitions of power relations within Korea played the central role ${ }^{[13]}$. Two distinct cultural camps clearly emerged out of these struggles. The first one, the withdrawn cultural camp, became particularly entrenched among the very extensive, traditional, more introverted and least competitive strata and sectors of Korean society and was more fully elaborated by intellectuals adhering to conservative ideologies. The second one, the underdog cultural camp, exhibits the opposite characteristics. It draws its intellectual origins from modernization. It is secular and extrovert in orientation and puts forward a reforming project aiming at making Korea an independent part of international polity. While the withdrawn cultural camp is largely influenced by conservative ideologies and put a stress on social stability, order and inevitable bonds with foreign big nations, the underdog cultural camp pursues social, political and economic reform in order to promote Korea's autonomous integration into the global society and reunification between South Korea and North Korea.

The general schema has been directly linked to the question of Korean Populism, with President Roh assigning reformist populism a place in the underdog cultural camp. Thus, although Roh's so-called codepolitics that led to the extremely dualistic cognition of political behavior is not primarily focused on populism, it offers an interesting framework on Korean culture within which populism can be neatly situated. In this framework Korean populism would be associated with the political culture of the underdog. Like most societies that have experienced a delayed development in comparison with the West, Korea is marked by a continuous and diffuse split between the antagonistic types of political culture: a traditionally oriented, conservative type, inward and hostile to reformist ideals and a progressive type that tries to adopt desirable institutions and catch-up with the West.

Such a view is also congruent with the signifying realities of populist discourses themselves insofar as in populism the people are often presented as the underdog which is oppressed, exploited or excluded from the status quo ${ }^{[11]}$. We have seen this pattern being reproduced in President Roh's discourses. In fact the whole struggle around the current political crisis lends itself very easily to an analysis along the lines of the manic dualism thesis. The two major actors seem to be leading two opposed cultural camps: the progressives struggling to reform the whole Korean society are led by President Roh who have been supported by some progressive intellectuals, long before the current crisis, as an advocate of political reform, while the conservative camp is led by a representative of a supposedly outdated institution claiming its force from the privileged past. In fact the issue of introducing class-action suits mentioned beforehand is regarded as an example of the tensions arising between the two cultural camps.

Albeit an important instrument for understanding Korean political culture, the manic dualism could have been the object of some criticism. For instance, McGuigan has pointed to the fact that it is susceptible to the danger of all dualist representations: The sliding into a good/bad dualism, based on a quasi-democratic logic trends to downplay the complexity of the issues in question $^{[9]}$. He has questioned the dualist schema insofar as it simplifies the relation between the conservatives and the progressives and in some of its versions, reproduces and uncritically justifies an unqualified pattern of transition from one to the other. $\mathrm{He}$ has also criticized the essentialism usually entailed similar schemata insofar as the two cultural camps are 
understood as unified along the lines of two selfenclosed and given poles-essences ${ }^{[9]}$. There is little doubt that the manic dualism thesis, no matter how helpful in clarifying the issues at stake, seems to presuppose a particular conception of political subjectivity which indeed tends to simplify a rather more complicated social phenomena. We take it, perhaps unwillingly, implying that political subjects can belong, at any moment, either to the progressive or conservative cultural camp.

On a fairly general level, it seems to accept that the two different types of political culture correspond to different political identities. Of course, we have to highlight the cross-sectional nature of the two cultural camps, that is, the tendency to cut across institutions, strata, classes, or political parties in Korean society and not to become exclusively identified with any structure across time or even at any given moment. The qualification is quite important but fails to address the problem at the level of the subject; it does, so to speak, at the level of ideal type of political identities focusing on the ways in which social strata, institutions, parties and other collective entities related to these ideal types $^{[5]}$. Indeed there is not much discussion in many texts of Korean Studies, dealing the way manic dualism is played out within subjective identity apart from very few references to what they call the reformists of the underdog culture and to the fact that the underdog culture, despite fluctuations, can be said to claim the allegiance of a majority of the Korean population since independence ${ }^{[3]}$. In that sense, though not explicitly stated or analyzed, one of the possible conclusions drawn from the established texts of Korean Studies is that, at any given moment, each person can either be a conservative/progressive of the one or the other cultural camp. I think such a conclusion to be justified not only on the basis of a careful reading of the texts, but also based on recent introductory comments according to which the heterogeneous social strata and the political alliances linked to them which at any given moment function as bearers and expressions of the two cultures exhibit a remarkable stability as far as their synthesis is concerned $^{[11]}$.

Such a picture, although possibly representative of certain subjective positions located at the extremes of the two cultural camps, does not seem to take into account either the complexities of subjectivity highlighted by contemporary psychoanalytic sociopolitical theory or most importantly in a sustained way, an empirical reality in which the contradiction between the conservative and the progressive penetrates all cultural camps, any political identity and every individual or collective actor. In Korea, it is not unusual for political subjects and institutions to behave in a conservative way on one occasion and in a progressive way in the next. The same progressives who are supporting Roh's reformist government might be supportive of the traditional-conservative position as far as the class-action suits is concerned; the same conservatives that are opposing the class-action suits can show their approval of FTA with the USA which is supposed to enhance economic globalization. Such examples are indeed endless. Wilson himself has suggested that there is deep ambiguity marking Korean political identity, which makes us admire and hate, at the same time, anything coming from the Americanized world $^{[14]}$. This situation cannot be attributed merely to the instability of the equilibrium between the two selfenclosed cultural camps. On the contrary, this instability has to be accepted as a mark of each and every political identity, in each and every situation. Here, the role of populist politics is once more revealing.

The relation between the conservative and the progressive is not always an external one and in fact a struggle between different groups comprised of political subjects with more or less fully constituted selfidentities. It is also an internal relation, marking every subjective political identity insofar as every selfidentity articulates elements from both cultural camps in different degrees. The result is a series of complex subjective political identities often articulating contradictory subject positions, resulting in what we, from a psychoanalytic point of view, have called the split identity ${ }^{[4]}$. This way of seeing things does not necessarily maintain that the two cultural camps do not exist as such; it merely suggests that in their continuous effort to constitute and reproduce themselves as pure forms they often ignore or repress their internal tensions and interrelations-both at the subjective and collective level. Major targets for empirical studies can only be to reveal these tensions and interrelations no matter how often their traces are blurred by totalizing political discourses of any types.

Nonetheless, the populist desire seems to be virtually indistinguishable from the manic dualism that has characterized a wide range of reform movements throughout the societal democratization in Korea. For example, the will to renew politics, the vindication of the people and the presumed immediacy of their link with leader or party have been present in political mobilization that are not usually branded populist as in the Korean case.

The evidence for this link is mixed. In the more intuitive use of the term, Korean populism is a label applied to crowd-pleasing politicians hard to distinguish 
from demagogues who will make any kind of promise, no matter how unattainable, as long as it advances their cause and who will tweak with legal procedures and institutional arrangements shamelessly to adjust them to their own needs. Although this, of course, applies to other political mobilization too, the terminology of Korean populism also describes an ambiguous observance of democratic practices and a general dislike of authoritative institutional settings. The populist impatience-either on the side of the government or on the side of its opposition-with formalized decision-making processes leads them to invoke their trademark distrust of any elite differentiation as a sweeping device to override institutional constraints on their actions. Perhaps one can attribute this to their inexperience with the intricacies of the legislative and judicial process, for they see themselves, legitimately or not, as political outsiders. Whatever the reason, their disdain for the procedural channels and for the checks and balances of the democratic process reflects a strong antiestablishment ethos that might explain why conservatives in Korea are not particularly keen on populism. Yet, even when these latter-day populists warp the operational mechanisms of a democratic framework of politics-representation, partisan competition, accountability and due process of law-, they invest considerable energy in defending their democratic credentials and reassuring critics of their observance of that framework. Either as mere posturing or as an actual practice, the democratic vindication is a part of populist politics. That is why Korean populism is not an accident but a recurrent trait of democratic politics, although the persistence of authoritarian variants is a reminder that one must keep a level head when thinking of this relation. If one looks at the phenomenon from the standpoint of the political subsystem, Korean populism appears to be a fellow traveler of contemporary, media-enhanced modes of representation at work in both emerging and wellestablished democracies. This would be fully compatible with the institutional regime form of democratic politics.

\section{CONCLUSION}

Here my argument concerning Korean populism shifts from the institutional site of the political regime to the imaginary of democratic politics.

According to Žižek's Lacanian work, we could attempt to interpret Korean populism as the return of the repressed, or better still, as a symptom of democratic politics, that is, as an internal element of the democratic system that also reveals its limits and prevents its closure. In his interpretation which hence reformulates Freud's, the symptom can be seen as the fundamental element of ideology. The working of ideology, he says, requires not so much a false consciousness among those who participate in a given social reality but they do not know what they are doing, in which case a symptom could be defined as a formation whose very consistency implies a certain non-knowledge on the part of the subject ${ }^{[15]}$. The subject can enjoy his symptom as long as its logic escapes him.

Let us connect this with the discussion about the internal relationship of Korean populism and democracy. What is the status of this relationship? I'd like to describe it as a mode of political representation, but the symptom offers us a different angle. Korean Populism as a symptom functions as a paradoxical element that both belongs to democracy and interrupts its closure as a gentrified or domesticated political order. Politics in representative democracy generally presupposes the priority of institutional mediations over charisma, the presence of checks and balances to limit the discretionary powers of political leaders, the widespread practice of reaching agreements through negotiations among political elites and so on. Korean Populism disrupts democracy by mounting its challenge on the redemptive face of democracy, often in detriment of law and order. As a promise of redemption, it exerts pressures on the presuppositions of representative democracy and to some extent warps them through the mobilization of the people to bypass institutional constraints. Either way, it plays the role of the awkward guest of the example; it is both an internal moment and a paradoxical element that disrupts the gentrified domain in which politics is enacted in liberal democracies. Put differently, populist politics in Korea undermines the fullness of any democratic expression of the will of the people, including its own.

In conclusion, Korean populism may function as a symptom of democratic politics in two senses. As a promise of redemption and as an index of reaction against politics as usual, it both disrupts the order of gentrification and expands the scope of citizen involvement in public affairs. Yet as the element that falls out of the gentrified system, it positions itself in the rougher edges of democratic politics, in a grey area where it is not always easy to distinguish populist mobilization from mob rule. In this interpretation, Korean populism might not necessarily break loose from a democratic setting, but it becomes something of an unstable phenomenon within that setting. It can be conceived both as a mirror in which democracy can 
scrutinize its more unsavory faces and as an experience that can become its underside.

\section{ACKNOWLEDGEMENTS}

I gratefully acknowledge the financial support for the research by the Institute for non-violence in Kyung Hee University through Human Korea Project in 21th Century, which has been implemented by Korea Research Foundation.

\section{REFERENCES}

1. Barros, S. and G. Castagnola, 2000. The Political Frontiers of the Social: Argentine Politics after Peronist Populism (1955-1973). In: Discourse Theory and Political Analysis: Identities, Hegemonies and Social Change, Howarth, D. and A. Norval (Eds.) Manchester University Press, Manchester and New York. pp: 24-37. ISBN: 0 719056640.

2. Canovan, M., 1999. Trust the people populism and the two faces of democracy. Political Stud., 47: 2-16. Doi: 10.1111/1467-9248.00184.

3. Cho, H.Y., 2006. The transformative crisis of democratic movement in Korea: Its cause and alternatives. Citizenship and World, 8: 18.-34 http://blog.peoplepower21.org/Research/30148.

4. Critchley, S., 2006. True Democracy: Marx, Political Subjectivity and Anarchic Meta-Politics. In: Radical Democracy: Politics between Abundance and Lack, Tønder, L. and L. Thomassen (Eds.) pp: 219-238. Manchester Univesity Press, Manchester and New York. ISBN10: 0719070449

5. Foucault, M., 2003. Society Must be Defended: Lectures at the College de France 1975-1976 (tr. D. Macey) Picador, New York, pp: 283-292. ISBN10: 0312422660 .
6. Kang, Man'gil, 1995. Contemporary Nationalist Movements and the Minjung. In: South Korea's Minjung Movement: The Cultural and Politics of Dissidence, (ed. K. Wells) pp. 31-38. University of Hawai'i Press, Honolulu. ISBN: 10: 0824817001.

7. Laclau, E., 1980. Populist rupture and discourse. Screen Education, 34: 87-93. http://www.antiqbook. com/books/bookinfo.phtml?o=psycho\&bnr=147037.

8. Laclau, E., 1977. Towards a Theory of Populism. In: Politics and Ideology in Marxist Theory: Capitalism, Fascism, Populism, Laclau, E. (Ed.) pp: 143-179. New Left Books, London. ISBN: 10: 0902308742.

9. McGuigan, J., 1992. Cultural Populism. Routledge. Ist Edn. London and New York. ISBN: 10: 0415062950 .

10. Mouzelis, N., 1985. On the concept of populism: Populist and clientelist modes of incorporation in semiperipheral politics. Politics Soc., 14: 329-348. http://pas.sagepub.com/content/vol14/issue3/.

11. Surel, Y. and Y. Mény, 2002. Democracies and the Populist Challenge. Ist Edn. Palgrave, New York. ISBN-10: 0333970047.

12. Taggart, P., 2000. Populism. Ist Edn. Open University Press, Buckingham. ISBN-10: 0335 200451.

13. Wells, K., 1995. The Cultural Construction of Korean History. In: South Korea's Minjung Movement: the Cultural and Politics of Dissidence Wells, K. (Ed.). University of Hawai'i Press, Honolulu, pp: 11-30. ISBN-10: 0824817001

14. Wilson, R., 1993. Theory's Imaginal Other: Amercian Encounter with South Korea and Japan. In: Japan in the World Miyoshi, J.M. and H. Harootunian, (Eds.). Duke University Press, Durham and London, pp. 316-337. ISBN-10: 0822313685.

15. Žižek, S., 2008. For they Know Not What they Do. Ist Edn. Verso, London, ISBN-10: 1844672123. 